Jurnal Pendidikan Indonesia Gemilang, Vol.1, No.1, 2021, pp. 1-6

e-ISSN 2807-5285. DOI. 10.53889/jpig.v1i1.17

\title{
Pengaruh Metode Pembelajaran Mneumonik terhadap Daya Ingat Siswa pada Konsep Protista
}

\author{
Disubmit 5 Agustus 2021, Direvisi 24 Agustus 2021, Diterima 28 Agustus 2021 \\ Anike Fifilusianty $\mathrm{WF}^{1^{*}}$, Mila Ermila Hendriyani ${ }^{2}$, Dian Rachmawati ${ }^{3}$ \\ Program Studi Pendidikan Biologi, Fakultas Keguruan dan Ilmu Pendidikan, \\ Universitas Sultan Ageng Tirtayasa, Serang, Indonesia \\ Email Korespondensi: *fifilusianty.nike@gmail.com
}

\begin{abstract}
Abstrak
Metode mneumonik yaitu metode menghafal dengan cara mengambil salah satu bagian kata yang akan dihafal untuk dirancang siswa menjadi susunan kata yang unik dan menjadi suatu kalimat yang familiar. Salah satu kesulitan siswa dalam mempelajari konten biologi adalah menghafal nama atau istilah latin, contohnya yang terkait dengan taksonomi. Penelitian ini bertujuan untuk mengetahui pengaruh metode mneumonik terhadap daya ingat siswa pada konsep protista di salah satu SMA Negeri di Kabupaten Tangerang, Indonesia. Metode kuasi eksperiment digunakan untuk mengukur variable daya ingat siswa, dengan desain Posttest Only Control Group Design. Sampel penelitian adalah kelas X IPA 3 sebagai kelas eksperimen dan X IPA 5 sebagai kelas kontrol yang diambil menggunakan teknik Simple random sampling. Uji hipotesis menggunakan t test diperoleh nilai thitung $9.124>$ ttabel sebesar 2.02. Nilai tersebut menunjukkan bahwa metode pembelajaran mneumonik berpengaruh terhadap daya ingat siswa pada konsep protista.
\end{abstract}

Kata Kunci: daya ingat, metode mneumonik, protista

\section{PENDAHULUAN}

Salah satu kesulitan siswa dalam mempelajari konten biologi adalah menghafal nama atau istilah latin, contohnya yang terkait dengan taksonomi. Siswa membutuhkan metode alternatif untuk memudahkan dalam menghafal dan mengingat materi-materi tersebut. Mengingat merupakan salah satu dari kemampuan kognitif yang menekankan pada kemampuan menarik kembali informasi yang tersimpan dalam memori jangka panjang (Widodo, 2005). Kemampuan mengingat pada siswa menunjukkan bahwa siswa itu mampu menyimpan dan mengeluarkan kembali sesuatu yang pernah didapatnya selama proses pembelajaran. Oleh karena itu, untuk mengetahui keberhasilan belajar, siswa dituntut untuk memiliki daya ingat atau kemampuan untuk mengingat suatu hal yang telah dipelajarinya. Salah satu metode yang dapat digunakan untuk membantu siswa dalam mengingat adalah metode mneumonik (Purnamasari, 2018).

Metode mneumonik yaitu metode menghafal dengan cara mengambil salah satu bagian kata yang akan dihafal untuk dirancang siswa menjadi susunan kata yang unik dan menjadi suatu kalimat yang familiar. Melalui latihan penggunaan mneumonik mampu mengoptimalkan daya ingat siswa terutama pada materi yang berhubungan dengan hafalan (Suharnan, 2005). Studi pendahuluan tentang kemampuan mengingat siswa dengan model pembelajaran CTL ataupun langsung akan memberikan daya ingat yang lebih baik pada siswa dibandingkan dengan menggunakan media charta. Purwati (2012) menyatakan bahwa teknik menumonik 
yang digunakan dalam proses pembelajaran dapat memfasilitasi siswa untuk mengingat materi yang diajarkan, hal ini disebabkan karena teknik menumonik membuat materi Biologi yang padat menjadi lebih ringan untuk dihapal. Namun, hingga saat ini penggunaan metode mneumonik untuk mengukur variable daya ingat siswa masih jarang dilaporkan/belum dilaporkan.

Dari pemaparan latar belakang di atas, dibutuhkan penelitian mengenai metode mneumonik yang diharapkan dapat mempermudah siswa dalam menghafal serta mengetahui pengaruh metode pembelajaran mneumonik terhadap daya ingat siswa pada konsep protista.

\section{METODE}

Penelitian dilaksanakan di SMAN 3 Kabupaten Tangerang. Penelitian ini termasuk dalam penelitian kuasi eksperimen (eksperimen semu) dengan desain penelitian Posttest Only Control Group Design. Pengambilan sampel menggunakan teknik Simple random sampling. Sampel yang digunakan dalam penelitian ini adalah kelas X IPA 3 sebagai kelas eksperimen dan X IPA 5 sebagai kelas kontrol di salah satu SMA Negeri di Kabupaten Tangerang, Indonesia.

Teknik pengumpulan datanya nontes, lembar tes objektif instrumennya dengan bentuk soal pilihan ganda sebanyak 20 butir. Soal pilihan ganda tersebut sebelumnya sudah diuji validitas, relibilitas, daya pembeda dan tingkat kesukaran. Menguji validitas soal menggunakan rumus korelasi Product moment. Rumus yang digunakan adalah:

$$
r_{x y}=\frac{N \sum X Y-\left(\sum X\right)\left(\sum Y\right)}{\sqrt{\left\{N \sum X^{2}-\left(\sum X\right)^{2}\right)},\left(N \sum Y^{2}-\left(\sum Y\right)^{2}\right\}}
$$

(Riduwan, 2012)

Sedangkan untuk reliabilitas menggunakan rumus :

$$
\mathrm{r}_{11}=\frac{2 r 1 / 2}{(1+r 1 / 2)}
$$

(Riduwan, 2012)

Selang waktu dua minggu setelah posttest dilakukan tes ulang (retest). Data ini diambil untuk mengukur hasil belajar pada aspek kognitif daya ingat siswa terhadap materi protista dengan menggunakan metode mneumonik. Non tes berupa angket dan lembar observasi kegiatan pembelajaran digunakan untuk mengetahui keterlaksanaan rancangan pembelajaran. Uji t digunakan untuk analisis data yang diperoleh yang sebelumnya telah dilakukan uji normalitas menggunakan rumus Chi-Kuadrat $\left(\mathrm{X}^{2}\right)$ dan uji homogenitas. 
Jurnal Pendidikan Indonesia Gemilang, Vol.1, No.1, 2021, pp. 1-6 e-ISSN 2807-5285. DOI. 10.53889/jpig.v1i1.17

\section{HASIL DAN PEMBAHASAN}

Rata-rata nilai posttest siswa di kelas kontrol dan eksperimen tidak berbeda nyata namun perbedaan semakin terlihat pada nilai retest dan daya ingat yaitu sebesar 19,26 dan 15,31. Hal itu menunjukkan bahwa dalam jangka waktu yang sama, siswa di kelas eksperimen lebih mampu untuk menyimpan dan mengambil kembali materi yang telah dipelajarinya. Rata-rata nilai posttest yang diperoleh pada kelas kontrol dan eksperimen cukup tinggi yaitu 85 dan 91,87. Namun, ketika dua minggu kemudian dilakukan retest nilai rata-rata siswa mengalami penurunan menjadi 60,61 pada kelas kontrol dan 79,87 pada kelas eksperimen. Penurunan tersebut dapat terjadi karena ketika pembelajaran berlangsung dari soal yang diberikan kepada siswa tidak seluruhnya dibuat akronim dan akrostik. Faktor selanjutnya adalah lupa, lupa merupakan ketidakmampuan otak untuk mengenal atau mengingat kembali materi yang telah dipelajari sebelumnya (Syah, 2010). Besarnya penurunan nilai yang diperoleh siswa ketika retest menunjukan kemampuan daya ingat siswa setelah mengikuti pembelajaran.

Penurunan nilai menunjukkan bahwa dalam waktu dua minggu siswa tidak mampu menggali informasi kembali yang sudah diperolah sebelumnya. Selama selang waktu tersebut siswa juga menerima banyak materi pelajaran lain yang masuk ke dalam ingatannya. Oleh karena itu, siswa mengalami kesulitan untuk memanggil kembali informasi yang telah lebih dulu didapatnya. Pendapat ini sama dengan yang diungkapkan oleh Syah (2010) yang menyebutkan bahwa materi pelajaran baru akan mengganggu pemanggilan kembali materi lama yang telah tersimpan. Hasil yang berbeda ditunjukkan oleh kelas eksperimen karena siswa dibimbing untuk lebih kreatif dalam menghafalkan materi pelajaran. Materi pelajaran yang disampaikan dibuat menjadi rangkaian kata yang unik membuat siswa dapat mengimajinasikan sesuatu yang akan diingatnya. Hal ini berpengaruh ketika siswa diberikan soal retest, maka mereka dapat lebih mudah mengingat kembali informasi yang telah didapatnya dengan maksimal. Semakin tepat cara yang digunakan untuk mengingat maka, daya serap dan kemampuan otak untuk mengingat juga akan semakin maksimal (Gunawan, 2007).

Perbedaan rata-rata nilai daya ingat siswa pada kelas kontrol dan eksperimen tidak berbeda nyata setelah diuji statistik. Kelas kontrol pada kategori baik dan kelas eksperimen pada kategori sangat baik. Hal tersebut menunjukkan bahwa walaupun di kelas kontrol terjadi penurunan nilai retest yang lebih besar pada kelas kontrol tetapi ketika posttest, siswa masih dapat mengingat materi yang diberikan dengan sangat baik. Siswa pada kelas kontrol masih dapat mengingat materi dengan sangat baik ketika posttest dapat disebabkan karena materinya mudah dikuasai siswa walaupun tidak dengan menggunakan metode mneumonik. Faktor lain yang menyebabkan kategori daya ingat siswa antara kelas kontrol dan eksperimen tidak berbeda 
nyata, adalah adanya interaksi antara kelompok eksperimen dan kelas kontrol di luar proses eksperimen yang tidak dapat dicegah oleh peneliti. Menurut Slameto (2010), hasil belajar siswa dapat dipengaruhi oleh faktor yang berasal dari luar maupun dari dalam diri siswa seperti motivasi untuk belajar.

Rekapitulasi hasil tes daya ingat siswa pada kelas kontrol dan eksperimen dikelompokkan menjadi beberapa kategori yaitu sangat baik rentang nilai 80-100, baik rentang nilai 70-79, cukup rentang nilai 60-69, kurang rentang nilai 50-59 dan sangat kurang rentang nilai ,50. Daya ingat siswa pada kelas kontrol dan eksperimen berdasarkan kategori tersebut diilustrasikan pada Gambar 1.

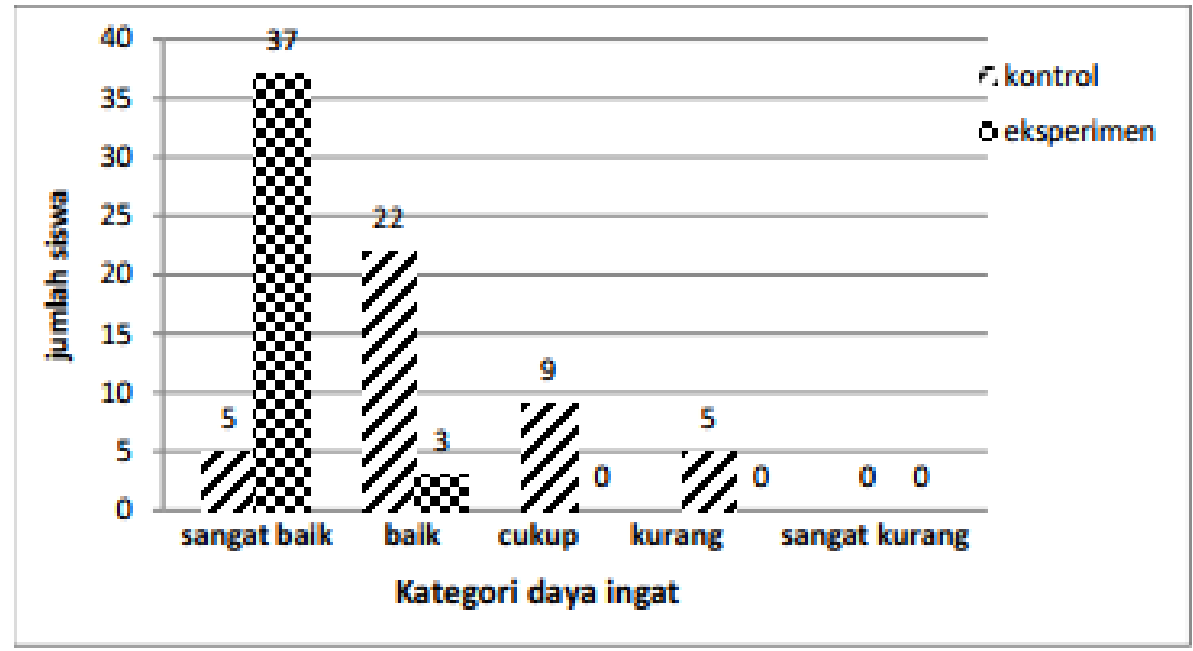

Gambar 1. Kategori daya ingat siswa di kelas kontrol dan kelas eksperimen

Ditemukan perbedaan daya ingat siswa pada kelas eksperimen dan kontrol, yaitu daya ingat siswa termasuk ke dalam kategori sangat baik pada kelas eksperimen (37 siswa), sedangkan pada kelas kontrol termasuk ke dalam kategori baik (22 siswa). Pada kelas kontrol tidak semua siswa mampu mengingat kembali dengan baik materi yang disimpan dan telah dipelajari sebelumnya. Menurut Gunawan (2007), salah satu yang menjadi hambatan siswa dalam mengingat yaitu banyaknya informasi yang diterima oleh otak sehingga dianggap menjadi tidak penting dan mengurangi minat siswa untuk mempelajarinya. Siswa pada kelas kontrol yang belajar dengan cara konvensional terlihat lebih cepat bosan dan kurang tertarik sehingga materi yang diserap pun tidak maksimal. Siswa yang merasa bosan dan ditambah dengan penumpukkan materi baru yang diterima oleh otak mempengaruhi siswa, sehingga mereka mengalihkan perhatiannya kepada hal lain diluar materi yang diajarkan. Sejalan dengan Suharnan (2005) bahwa informasi baru yang didapat oleh siswa dapat menjadi penghalang bagi siswa untuk mengingat informasi yang telah diterimanya lebih dulu.

Siswa pada kelas eksperimen lebih mudah menyerap informasi dan dapat mengingatnya kembali dengan sangat baik (Gambar 1). Hal ini terlihat dengan 
Jurnal Pendidikan Indonesia Gemilang, Vol.1, No.1, 2021, pp. 1-6

e-ISSN 2807-5285. DOI. 10.53889/jpig.v1i1.17

banyaknya siswa dengan kategori daya ingat sangat baik. Melalui pembelajaran mneumonik, siswa dilibatkan untuk membuat kata-kata unik mengenai materi yang dipelajari, sehingga lebih mudah dihafal dan mengingatnya dari memori ketika dibutuhkan kembali. Hasil tersebut sejalan dengan pernyataan Buzan (1986), bahwa dengan adanya petunjuk-petunjuk tentang informasi yang dibutuhkan, maka memungkinkan siswa untuk mengingat kembali informasi tersebut dengan baik.

Berdasarkan hasil angket respon siswa terhadap pembelajaran menggunakan metode mneumonik diketahui bahwa siswa sangat senang diajarkan cara mudah untuk menghafal materi pelajaran melalui metode mneumonik. Metode mneumonik membuat materi biologi yang syarat akan hafalan menjadi lebih ringan, sehingga siswa pun menjadi lebih tertarik untuk mempelajarinya lebih lanjut. Siswa juga mengungkapkan bahwa daya ingat mereka mengenai materi tersebut menjadi lebih baik karena telah diajarkan cara mudah untuk mengingatnya.

Hasil analisis data uji signifikasi pengaruh metode pembelajaran mneumonik terhadap daya ingat siswa diolah menggunakan spss versi 13. Perolehan rata-rata daya ingat pada kelompok kontrol sebesar 71,57 dengan kategori baik dan pada kelompok eksperimen sebesar 86,88 dengan kategori sangat baik. Data yang diperoleh kemudian dianalisis untuk menjawab hipotesis yang dibuat dengan menggunakan uji t.

Pengaruh metode mneumonik terhadap daya ingat siswa pada $\alpha=0,05$ dilihat dari nilai thitung (9.124) lebih besar dari ttabel (2.02) yang artinya H0 ditolak dan H1. Oleh karena itu terdapat pengaruh metode pembelajaran mneumonik terhadap daya ingat siswa pada konsep Protista.

Metode pembelajaran mneumonik berpengaruh terhadap daya ingat siswa dimungkinkan karena metode tersebut memiliki beberapa kelebihan. Antara lain; materi yang diingat siswa dibuat lebih menarik karena dibuat kata-kata yang unik berupa akronim dan akrostik. Penggunaan kata-kata unik sesuai dengan hal-hal yang disukai otak. Menurut Gunawan (2007), hal yang disukai otak yaitu bersifat tidak masuk akal, melibatkan emosi, imajinasi, dan humor. Kelebihan yang kedua yaitu penyampaian yang diselingi dengan pemberian akronim atau akrostik membuat materi menjadi tidak membosankan, siswa juga dapat mengimajinasikannya sehingga menguatkan materi yang akan diingat. Lucy dan Rizky (2012) menyatakan bahwa ingatan siswa mengenai hal-hal yang abstrak akan diperkuat dengan adanya imajinasi. 
Jurnal Pendidikan Indonesia Gemilang, Vol.1, No.1, 2021, pp. 1-6 e-ISSN 2807-5285. DOI. 10.53889/jpig.v1i1.17

Penggunaan metode mneumonik dalam pembelajaran memberikan perbedaan yang signifikan antara kelas kontrol dan kelas eksperimen. Metode mneumonik merupakan metode yang memudahkan siswa dalam mengingat materi pelajaran karena melibatkan katakata dan imajinasi. Siswa dibentuk menjadi beberapa kelompok untuk kemudian membuat akronim dan akrostik dari materi yang telah disampaikan. Akronim dan akrostik tersebut selanjutnya digunakan untuk memudahkan siswa dalam mengingat materi tersebut. Selama proses pembelajaran Biologi pada konsep protista dengan menggunakan metode mneumonik, hampir sebagian besar rencana pembelajaran yang tersusun dalam RPP yang telah dibuat dapat dilaksanakan oleh peneliti dengan baik.

\section{KESIMPULAN}

Berdasarkan hasil dan pembahasan yang telah dipaparkan, maka dapat ditarik kesimpulan bahwa Penerapan metode mneumonik pada konsep Protista berpengaruh terhadap daya ingat siswa. Selain itu, akrostik dan akronim yang dibuat bisa menstimulasi ingatan siswa mengenai materi yang diajarkan.

\section{DAFTAR PUSTAKA}

Buzan, T. (1986). Use Your Memory. Guild Publishing, London.

Gunawan, A. 2007.Genius Learning Stategy.Penerbit Gramedia Pustaka Utama. Jakarta.

Lucy, B. \& A.J. Rizky.2012.Dahsyatnya Brain Smart Teaching. Penebar plus+ Jakarta.

Purnamasari, R. (2018). Strategi Pembelajaran Mnemonic untuk Meningkatkan Memori Siswa. SIPATAHOENAN, 4(2).

Purwati, P. 2012. Pemahaman Konsep dan Retensi Siswa pada Pembelajaran Menggunakan Pendekatan Brain Based Learning di SMAN 4 Kota Tangerang. Skripsi Universitas Sultan Ageng Tirtayasa: Tidak diterbitkan.

Riduwan. 2012.Belajar mudah penelitian untuk guru, karyawan, dan peneliti pemula. Alfabeta, Bandung.

Slameto. 2010. Belajar dan Faktor-faktor yang Mempengaruhinya. Rineka Cipta, Jakarta.

Suharnan. 2005. Psikologi Kognitif. Kaifa, Bandung.

Syah, M. 2010. Psikologi Pendidikan. Remaja Rosdakarya, Bandung.

Widodo, A. 2006.Taksonomi Bloom dan Pengembangan Butir Soal.Buletin Puspendik. 3(2), 18-29. 